\title{
UPAYA PENINGKATAN HASIL BELAJAR GEOGRAFI MELALUI MEDIA PERMAINAN EDUKATIF ULAR TANGGA TEMATIK PADA SISWA MAN 2 PONTIANAK
}

\author{
Rina ${ }^{1}$, Rika Anggela ${ }^{2}$ \\ ${ }^{1,2}$ Program Studi Pendidikan Geografi \\ Fakultas Ilmu Pendidikan dan Pengetahuan Sosial IKIP PGRI Pontianak \\ Jalan Ampera Nomor 88 Pontianak - 78116, Telepon (0561) 748219 Fax. (0561) 589855 \\ ${ }^{1}$ Alamat e-mail: rinac4hy4n1@gmail.com
}

\begin{abstract}
Abstrak
Tujuan umum dalam penelitian ini adalah untuk mengetahui informasi tentang penggunaan alat peraga ular tangga tematik untuk meningkatkan hasil belajar siswa dalam pembelajaran Geografi di kelas XI IPS MAN 2 Pontianak. Metode yang digunakan dalam penelitian ini adalah penelitian tindakan kelas sedangkan bentuk penelitiannya adalah penelitian tindakan kolaboratif. Subjek dalam penelitian ini adalah 1 orang Guru Geografi dan siswa kelas XI IPS 1 sebanyak 38 siswa. Alat pengumpulan data yaitu lembar observasi, soal tes, angket dan dokumentasi. Analisisi data yang digunakan adalah analisis kuantitatif dan kualitatif. Hasil penelitian diperoleh kesimpulan sebagai berikut: 1) Penggunaan alat peraga ular tangga tematik dalam pembelajaran geografi siklus I dan siklus II diperoleh bahwa Penggunaan alat peraga ular tangga tematik yang dilakukan dosen baik sekali, 2) Hasil belajar siswa Pra Siklus dengan ketuntasan klasikal sebesar 44,7\%, siklus I dengan ketuntasan klasikal sebesar 42,1\%, siklus II dengan ketuntasan klasikal sebesar $100 \%$. Hasil belajar terjadin peningkatan yang signifikan sehingga membawa dampak positif terhadap hasil belajar siswa.
\end{abstract}

Kata Kunci: ular tangga tematik; hasil belajar;

\begin{abstract}
The aim in the research was to find out information about the use of thematic ladder snake to increase of student learning outcomes in Geography on class XI IPS MAN 2 Pontianak. The method used in this research is classroom action research while the form of research is collaborative action research. The subjects in the research were 1 of Geography Teacher and 38 students in XI IPS 1. Data collection tools are observation sheets, test questions, questionnaires and documentation. Analysis of the data used is quantitative and qualitative analysis. The results of the research conclusions are : 1) The use of thematic ladder snake in the learning of geography cycle I and cycle II obtained that the use of thematic ladder snake by the lecturer was excellent, 2) Pre-Cycle student learning outcomes with classical completeness of $44,7 \%$, cycle I with classical completeness is $42.1 \%$, cycle II with classical completeness is $100 \%$. Learning outcomes occur a significant increase so that it brings a positive impact on student learning outcomes.
\end{abstract}

Keywords: thematic ladder Snake; learning outcome;

\section{PENDAHULUAN}

Pembelajaran merupakan suatu sistem yang terdiri atas berbagai komponen yang saling berhubungan satu dengan yang lain. Komponen tersebut meliputi tujuan, materi, metode, atau model dan evaluasi. Bahan pembelajaran 
dapat berupa pengetahuan, nilai-nilai kesusilaan, seni, norma agama, sikap, dan keterampilan. Hubungan antara guru, siswa, dan bahan ajar bersifat dinamis dan kompleks. Hakikatnya belajar merupakan interaksi antara siswa dengan lingkungan. Oleh karena itu, untuk mencapai hasil belajar yang optimal perlu keterlibatan siswa atau partisipasi siswa yang tinggi dalam pembelajaran. Keterlibatan siswa merupakan hal yang sangat penting dalam menentukan keberhasilan. Kegiatan belajar mengajar yang melahirkan interaksi antara guru dan siswa merupakan suatu proses dalam rangka mencapai tujuan pengajaran.

Peningkatan hasil belajar perlu lebih aktif dilakukan untuk membangun dinamika kelas. Sudjana (2016) mengatakan, bahwa: "hasil belajar adalah kemampuan-kemampuan yang dimiliki siswa setelah ia menerima pengalaman belajarnya", sedangkan Zuldafrial (2009) mengemukakan "hasil belajar pada dasarnya adalah merupakan suatu proses mental karena orang yang belajar perlu memikir, menganalisa, mengigat, dan mengambil kesimpulan dari apa yang dipelajari". Bekerjasama dalam belajar siswa diharapkan mampu berfikir dan mengembangkan keaktivannya tanpa rasa takut atau malu terhadap guru ketika kegiatan belajar mengajar berlangsung. Di samping itu, hasil belajar siswa akan meningkat bila ada sarana yang membantu salah satunya media. Media pendidikan adalah segala jenis sarana pendidikan yang digunakan sebagai perantara dalam kegiatan proses belajar mengajar untuk meningkatkan efektivitas dan efesiensi pencapaian tujuan pendidikan. Salah satu bentuk media adalah permainan. Permainan dapat menjadi sumber belajar atau media belajar apabila permainan tersebut bertujuan untuk mencapai tujuan pendidikan atau pembelajaran. Permainan dapat membuat suasana lingkungan belajar menjadi menyenangkan, segar, hidup, bahagia, santai namun tetap memiliki suasana belajar yang kondusif.

Madrasah Aliyah Negeri 2 Pontianak merupakan salah satu sekolah yang telah menerapkan Kurikulum 2013. Berdasarkan hasil wawancara dengan guru Geografi kelas X IPS di MAN 2 Pontianak pada tanggal 215 Maret 2019, hasil belajar siswa pada kelas X IPS di MAN 2 Pontianak tahun ajaran 2019/2020 masih tergolong rendah dibandingkan dengan kelas yang lainnya. 
Kenyataannya berdasarkan hasil observasi yang dilakukan oleh peneliti, tingginya persentase ketidaktuntasan siswa kelas X IPS pada mata pelajaran Geografi dikarenakan kurangnya motivasi dan semangat belajar dari dalam diri siswa. Selain itu kurangnya media atau alat bantu untuk menjadi sarana penyampaian materi yang belum terfasilitasi oleh sekolah juga menjadi faktor penyebab rendahnya motivasi belajar siswa yang berdampak pada hasil belajar siswa. Siswa juga belum bisa menerima pelajaran dengan baik, kadang siswa tidak konsentrasi dalam mengikuti pelajaran, bahkan disaat guru menjelaskan masih ada juga siswa yang masih mencatat. Pembelajaran seperti ini mengakibatkan kurangnya gairah, motivasi dan perhatian siswa dalam proses belajar mengajar sehingga ada siswa yang berbicara, merasa bosan, dan malas ketika proses belajar mengajar berlangsung, hal ini ditunjukkan dengan rata-rata nilai ulangan umum Geografi siswa kelas X IPS yaitu 67,06 dan persentase ketuntasan siswa adalah 51,51\%.

Terkait dengan hal tersebut, maka peneliti mencoba untuk melakukan uji coba pembelajaran Geografi pada siswa kelas X IPS tahun ajaran 2019/2020 dengan menerapkan media dalam bentuk permainan. Salah satu permainan yang dapat digunakan menjadi media pembelajaran adalah permainan ular tangga. Sebagaimana yang dikatakan oleh Husna (dalam Listyani, 2017) bahwa permainan ular tangga adalah suatu permainan yang menggunakan dadu untuk menentukan beberapa langkah yang harus dijalani bidak atau pemain.

Papan permainan dalam ular tangga berupa gambar kotak-kotak yang terdiri dari 10 baris dan 10 kolom dengan nomor 1-100, serta terdapat gambar ular dan tangga. Permainan ular tangga mungkin sudah tidak asing lagi bagi semua orang karena mudah didapatkan. Namun kali ini permainan ular tangga dapat dijadikan suatu model, media, dan strategi pembelajaran bagi siswa. Alat permainan edukatif ular tangga sangat menarik. Salah satu kelebihan pokok adalah pada visualisasi yang menyenangkan dapat mengaktifkan semua indera siswa sehingga stimulasi yang masuk dapat dengan mudah dicerna, anak memperoleh pemahaman dan kebermaknaan bagi hidupnya. Model pembelajaran yang mampu melibatkan keaktivan siswa secara menyeluruh juga perlu dikembangkan sehingga kegiatan belajar mengajar tidak hanya didominasi oleh 
siwa-siswa tertentu saja. Permainan ular tangga bertujuan untuk membentuk kemandirian, karena merupakan media pembelajaran yang memiliki pola learning by doing. Berdasarkan pola tersebut siswa sebagai pemain dituntut untuk belajar sehingga dapat menyelesaikan masalah yang dihadapi. Pembelajaran tematik merupakan pendekatan pembelajaran yang melibatkan beberapa mata pelajaran untuk memberikan pengalaman belajar yang bermakna bagi anak. Pembelajaran tematik secara efektif membantu anak menciptakan kesempatan membangun konsep-konsep yang saling berkaitan yang diikat oleh satu tema. Dengan demikian, pembelajaran tematik memberikan kesempatan pada siswa untuk memahami masalah yang kompleks yang ada di lingkungan sekitarnya dengan pandangan yang utuh. Dengan demikian siswa diharapkan memiliki kemampuan untuk mengidentifikasi, mengumpulkan, menilai, dan menggunakan informasi yang ada di sekitarnya secara bermakna, Hernawan dan Resmini (dalam Indriasih, 2017).

Media ular tangga tematik dapat mendorong siswa untuk dapat memberikan tanggapannya secara bebas, siswa dilatih untuk dapat bekerja sama dan menghargai pendapat orang lain, membuat suasana pembelajaran yang kooperatif antara siswa dengan siswa dan antara siswa dengan guru. Cara ini akan lebih memotivasi siswa untuk berinteraksi dan bereksplorasi seputar topik pembelajaran yang ada, saling membantu, berdiskusi dan berargumentasi mengemukakan idenya sambil bermain. Dalam proses pembelajaran guru hendaknya mengupayakan setiap penjelasan yang diberikan dapat menumbuhkan perhatian dan motivasi belajar bagi siswa. Apabila guru menerapkan metode atau model pembelajaran tidak sesuai dengan kelas maka sistem belajar mengajar tidak dapat berjalan sesuai yang diharapkan. Harapan untuk kedepanya adalah kreativitas guru dalam menggunakan alat peraga ular tangga tematik dalam meningkatkan hasil belajar siswa pada mata pelajaran geografi khususnya pada kelas XI IPS MAN 2 Pontianak dapat digunakan lebih maksimal.

\section{METODE}


Metode yang digunakan dalam penelitian ini adalah metode Penelitian Tindakan Kelas (PTK) sebab penulis hendak Mencari informasi permasalahan dalam pengembangan pemikiran pada peserta didik. Bentuk penelitian yang dipakai adalah penelitian tindakan kolaboratif. Menurut Suharsimi Arikunto, (2007: 17) dalam penelitian kolaborasi, pihak yang melakukan tindakan adalah guru itu sendiri, sedangkan yang diminta melakukan pengamatan terhadap berlangsungnya proses tindakan adalah peneliti, bukan guru yang sedang melakukan tindakan.

Subjek penelitian pada penelitian kali ini adalah siswa kelas XI IPS1 MAN 2 Pontianak sebanyak 38 siswa. Peran peneliti dalam penelitian ini adalah sebagai observer, pengumpul data, penganalisis data dan sekaligus pelapor hasil penelitian. Guru melakukan tindakan untuk meningkatkan mutu pembelajaran dengan metode yang lebih baik dari sebelumnya.

Teknik pengumpulan data yang digunakan dalam penelitian ini adalah : observasi langsung, Pengukuran dan studi dokumenter. Adapun alat pengumpulan data adalah : panduan observasi, Tes, dan dokumentasi. Analisis data penelitian tindakan kelas berupa deskriptif kualitatif dan deskriptif kuantatif. Analisis deskriptif kualitatif dalam penelitian ini bersifat menggambarkan fakta yang sesuai data yang diperoleh untuk mengetahui kecerdasan kreatif yang diperoleh siswa secara kualitatif selama proses pembelajaran. Selain itu, untuk mengetahui kecerdasan kreatif siswa dalam berdiskusi terhadap kegiatan pembelajaran.

$$
\bar{X}=\frac{\sum x}{N}
$$

Keterangan :

$\bar{X}=$ Rata-rata hitung yang dicari

$\sum \mathrm{x}=$ Jumlah skor

$\mathrm{N}=$ Jumlah subjek

(Sudjana, 2016: 109)

Pengukuran keberhasilan dalam pelaksanaan tindakan yang dilakukan, maka ditetapkan indikator kinerjanya menggunakan rumus tingkat ketuntasan klasikal antara lain sebagai berikut: 


\section{Ketuntasan belajar = Jumlah siswa tuntas x $100 \%$ Jumlah semua siswa}

Indikator pengukuran keberhasilan secara relatif ditentukan berdasarkan keadaan, karakteristik daerah sekolah dan juga kemampuan siswa. Sementara MAN 2 Pontinak menetapkan ketuntasan belajar secara klasikal yaitu $\geq 75 \%$ dari jumlah seluruh siswa.

\section{HASIL DAN PEMBAHASAN}

\section{Penggunaan Media Ular Tangga Tematik}

\section{Siklus I}

Selama siklus I, kegiatan pembelajaran berlangsung dengan yang berlangsung secara lancar pada materi Flora dan Fauna. Siklus I diikuti siswa kelas X IPS1 yang berjumlah 38 siswa. Untuk melihat penggunaan media ular tangga tematik pada tabel sebagai berikut:

Tabel 1. Penggunaan Media Ular Tangga Tematik Siklus I

\begin{tabular}{|c|l|c|c|}
\hline No. & $\begin{array}{c}\text { Komponen Rencana } \\
\text { Pembelajaran }\end{array}$ & Skor & Ket \\
\hline I & Pra Pembelajaran & 4 & $\begin{array}{c}\text { Baik } \\
\text { Sekali }\end{array}$ \\
\hline II & Membuka Pembelajaran & 4 & $\begin{array}{c}\text { Baik } \\
\text { Sekali }\end{array}$ \\
\hline III & $\begin{array}{l}\text { Kegiatan Inti } \\
\text { Pembelajaran }\end{array}$ & 3,1 & Baik \\
\hline IV & Penutup & 3,3 & Baik \\
\hline \multicolumn{2}{|c|}{ Skor Total (I+II+III+IV) } & \multicolumn{2}{|c|}{14,4} \\
\hline \multicolumn{2}{|c|}{ Rata-rata Skor IPKG 2 } & 3,6 & $\begin{array}{c}\text { Baik } \\
\text { Sekali }\end{array}$ \\
\hline
\end{tabular}

Berdasarkan hasil observasi yang telah dilakukan terhadap pelaksanaan pembelajaran dengan menggunakan instrumen yang telah disiapkan diketahui bahwa pelaksanaan pembelajaran dengan menggunakan media ular tangga masuk dalam kategori baik sekali dengan rata-rata skor sebesar 3,6. Guru melaksanakan pembelajaran dari awal sampai akhir mengikuti langkah yang seharusnya 
dilakukan dalam menggunakan media ular tangga tematik. Setiap tahap dilakukan sungguh-sungguh dan seksama.

\section{Siklus II}

Adapun penggunaan media ular tangga tematik dapat dilihat pada tabel sebagai berikut:

Tabel 2. Penggunaan Media Ular Tangga Tematik Siklus II

\begin{tabular}{|c|l|c|c|}
\hline No. & $\begin{array}{c}\text { Komponen Rencana } \\
\text { Pembelajaran }\end{array}$ & Skor & Ket \\
\hline I & Pra Pembelajaran & 4 & $\begin{array}{c}\text { Baik } \\
\text { Sekali }\end{array}$ \\
\hline II & Membuka Pembelajaran & 4 & $\begin{array}{c}\text { Baik } \\
\text { Sekali }\end{array}$ \\
\hline III & $\begin{array}{l}\text { Kegiatan Inti } \\
\text { Pembelajaran }\end{array}$ & 3,85 & $\begin{array}{c}\text { Baik } \\
\text { Sekali }\end{array}$ \\
\hline IV & Penutup & 3,7 & $\begin{array}{c}\text { Baik } \\
\text { Sekali }\end{array}$ \\
\hline \multicolumn{2}{|c|}{ Skor Total (I+II+III+IV) } & \multicolumn{2}{|c|}{15,6} \\
\hline \multicolumn{2}{|c|}{ Rata-rata Skor IPKG 2 } & 3,9 & $\begin{array}{c}\text { Baik } \\
\text { Sekali }\end{array}$ \\
\hline
\end{tabular}

Berdasarkan hasil observasi yang telah dilakukan terhadap pelaksanaan pembelajaran dengan menggunakan instrumen yang telah disiapkan diketahui bahwa pelaksanaan pembelajaran dengan menggunakan media ular tangga masuk dalam kategori baik sekali dengan rata-rata skor sebesar 3,9. Guru melaksanakan pembelajaran dari awal sampai akhir mengikuti langkah yang seharusnya dilakukan dalam menggunakan media ular tangga tematik. Setiap tahap dilakukan sungguh-sungguh dan seksama.

Pembelajaran dengan menggunakan media ular tangga tematik tercermin dari pelaksanaan pembelajaran pada siklus I dan siklus II. Kegiatan dalam pelaksanaan pembelajaran antara lain : a) Kegiatan Pra pembelajaran. Kegiatan ini dilaksanakan dengan baik sekali. Dosen secara cermat menyiapkan ruang, alat dan media yang akan digunakan dalam mendukung kegaiatan belajar pembelajaran, b) Kegiatan membuka pelajaran dilaksanakan dengan Baik Sekali. Dosen melaksanakan pembelajaran dimulai dengan apersepsi, informasi dari guru ke 
peserta didik mengenai tujuan dan materi pelajaran, c) Kegiatan inti berjalan dengan baik. Siswa menjalankan segala kegiatan dalam inti pembelajaran dengan baik dan benar. Walaupun masih ada kendala secara teknis. Kegiatan inti pembelajaran merupakan kegiatan yang sangat penting karena dapat terlihat sejauh mana penggunaan media ular tangga tematik dilaksanakan dalam pembelajaran, d) Kegiatan penutup dilaksanakan guru dengan baik sekali. Guru tidak langsung menutup pelajaran namun melaksanakan tanya jawab dan merefleksi kegiatan pembelajaran yang telah dilaksanakan. Untuk melihat sejauh mana pengetahuan dan pemahaman mahasiswa terhadap pembelajaran yang dilaksanakan.

\section{Hasil Belajar}

\section{Siklus I}

Adapun hasil belajar pada Siswa Kelas X IPS 1 pada Siklus I dapat dilihat pada tabel sebagai berikut:

Tabel 3. Persentase Ketuntasan Hasil Belajar Siklus I

\begin{tabular}{|l|l|l|}
\hline No. & \multicolumn{1}{|c|}{ Ketuntasan } & Persentase (\%) \\
\hline 1. & Tuntas & 42,1 \\
\hline 2. & Tidak Tuntas & 57,9 \\
\hline Jumlah & $\mathbf{1 0 0}$ \\
\hline
\end{tabular}

Berdasarkan data hasil penelitian pada Siklus I mengenai hasil belajar siswa diketahui bahwa rata-rata nilai hasil belajar siswa adalah adalah 73,1. Nilai rata-rata ini belum masuk dalam kriteria ketuntasan minimal (KKM) yang ditentukan sekolah adalah 75. Nilai terendah yang diperoleh siswa sebesar 66 dan nilai tertinggi adalah 83. Untuk presentase ketuntasan kelas yang diperoleh sebesar $42,1 \%$. Presentase klasikal yang diperoleh tersebut belum mencapai dalam indikator ketercapaian yang telah ditentukan.

\section{Siklus II}

Adapun hasil belajar pada Siswa Kelas X IPS 1 pada Siklus I dapat dilihat pada tabel sebagai berikut: 
Tabel 4. Persentase Ketuntasan Hasil Belajar Siklus I

\begin{tabular}{|l|l|l|}
\hline No. & Ketuntasan & Persentase (\%) \\
\hline 1. & Tuntas & 100 \\
\hline 2. & Tidak Tuntas & 0 \\
\hline Jumlah & $\mathbf{1 0 0}$ \\
\hline
\end{tabular}

Berdasarkan data hasil penelitian pada Siklus II mengenai hasil belajar siswa diketahui bahwa rata-rata nilai hasil belajar siswa adalah adalah 81. Nilai rata-rata ini masuk dalam kriteria ketuntasan minimal (KKM) yang ditentukan sekolah. Nilai terendah yang diperoleh siswa sebesar 73 dan nilai tertinggi adalah 86. Untuk presentase ketuntasan klasikal yang diperoleh sebesar 100\%. Presentase klasikal yang diperoleh tersebut telah mencapai dalam indikator ketercapaian yang telah ditentukan.

\section{Peningkatan Hasil Belajar Siswa Melalui Media Ular Tangga Tematik}

Tabel 5. Persentase Ketuntasan Hasil Belajar (Pra Tindakan, Siklus I, Siklus

\section{II)}

\begin{tabular}{|l|l|l|}
\hline & Tuntas & Tidak Tuntas \\
\hline Pra tindakan & $44,7 \%$ & $55,3 \%$ \\
\hline Siklus I & $42,1 \%$ & $57,9 \%$ \\
\hline Siklus II & $100 \%$ & $0 \%$ \\
\hline
\end{tabular}

Untuk lebih jelasnya dapat dilihat pada grafik berikut ini:

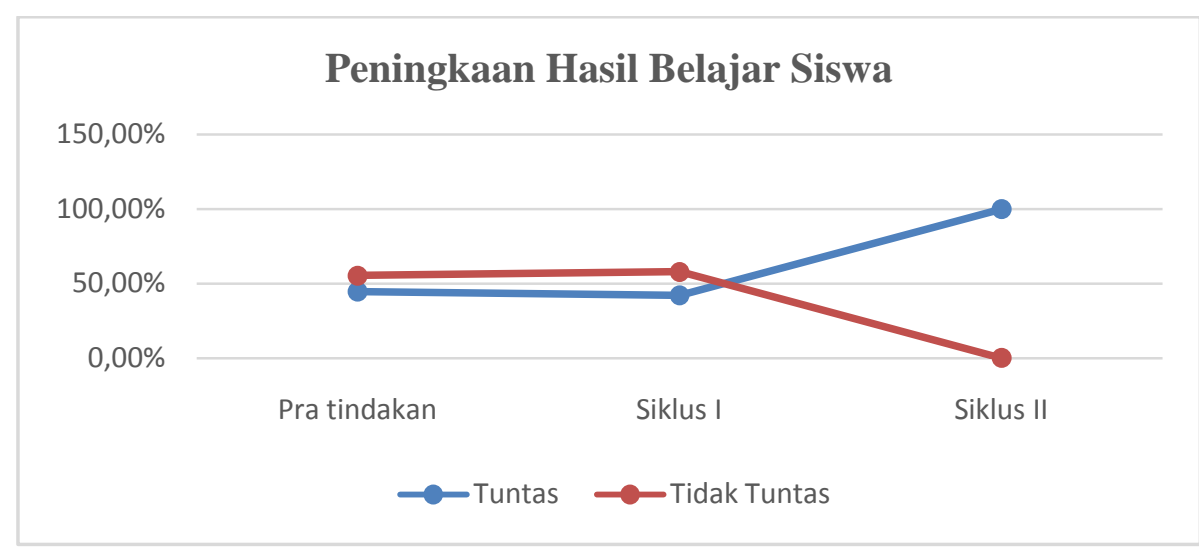

Gambar 1. Grafik peningkatan Ketuntasan Hasil Belajar Siswa 
Berdasarkan tabel 5 di atas dapat diketahui bahwa pada pra tindakan, hasil belajar siswa masih banyak yang belum masuk dalam kriteria tuntas dengan presentase sebesar $44,7 \%$. Hal ini terjadi sebagai gambaran bahwa masih banyak siswa yang belum menguasai pembelajaran. Siklus I, hasil belajar kelas XI IPS 1 mendapatkan perolehan persentase ketuntasan sebesar 42,1\%. Presentase tersebut belum mencapai indikator kinerja minimum sebesar 75\%. Pada siklus 1 untuk indikator ketuntasan klasikal mengalami penurunan walaupun tidak secara signifikan sebesar 2,6\% hal ini terjadi karena siswa masih beradaptasi dengan permainan dan belum banyak mempelajari kembali materi yang dibuat soal. Setelah melihat adanya penurunan, guru dan peneliti berdiskusi untuk dapat meningkatkan hasil belajar dengan melaksakan kembali pembelajaran dengan media ular tangga tematik. Peningkatan terlihat pada siklus II, hasil belajar siswa telah mencapai indikator ketercapaian yang telah ditentukan dimana rata-rata nilai sebesar 81 dengan persentase ketuntasan klasikal 100\%. Peningkatan pembelajaran yang terjadi pada Pembelajaran dengan menggunakan ular tangga tematik sejalan dengan penelitian yang dilakukan oleh Maisyaroh pada tahun 2014. Hal ini terjadi karena pada pelaksanaan pembelajaran dengan ular tangga tematik, siswa telah mampu mengikuti permainan dengan sangat baik sehingga siswa memiliki memori yang berkaitan dengan materi pembelajaran. Hal ini sejalan dengan kelebihan permainan ular tangga tematik yang dikemukakan Reysne (2017):

Media ular tangga tematik sangat praktis dan ekonomis serta mudah dimainkan. Selain itu, media ini juga sangat disenangi oleh murid karena banyak terdapat gambar yang menarik dan full color, dapat menarik minat siswa dalam belajar, serta mampu menumbuhkan kerjasama kelompok dalam mencapai finish sangat ditekankan. Juga menjadikan anak tidak selalu dituntut untuk berpikir, sehingga suasana pembelajaran cenderung lebih menyenangkan, dengan keberuntungan mengocok dadu, memberikan motivasi lebih besar pada siswa untuk belajar karena siswa akan termotivasi untuk mengikuti proses belajar dan memfokuskan siswa sebagai subjek materi yang dimasukkan ke dalam permainan. Hal ini disebabkan oleh rasa tertantang, motivasi, dan semangat yang tinggi. 
Dengan kelebihan ular tangga ini memberikan dampak terhadap peningkatan hasil belajar siswa dikarenakan siswa diawal telah merasa senang terhadap pembelajaran, memiliki motivasi dan semangat untuk belajar.

\section{SIMPULAN}

Hasil penelitian diperoleh kesimpulan sebagai berikut: 1) Penggunaan alat peraga ular tangga tematik dalam pembelajaran geografi siklus I dan siklus II diperoleh bahwa Penggunaan alat peraga ular tangga tematik yang dilakukan dosen baik sekali, 2) Hasil belajar siswa Pra Siklus dengan ketuntasan klasikal sebesar 44,7\%, siklus I dengan ketuntasan klasikal sebesar 42,1\%, siklus II dengan ketuntasan klasikal sebesar $100 \%$. Hasil belajar terjadinya peningkatan yang signifikan sehingga membawa dampak positif terhadap hasil belajar siswa.

\section{DAFTAR PUSTAKA}

Indriasih, Aini. (2017). Pemanfaatan Alat Permainan Edukatif Ular Tangga dalam Penerapan Pembelajaran Tematik. Skripsi UPBJJ-UT: Semarang.

Listyani, Amin. (2017). Pengembangan Board Game Ular Tangga Berbasis Keragaman Budaya Untuk Kelas III SD N Kota Gede 5 Yogyakarta. Skripsi Universitas Negeri Yogyakarta: Yogyakarta.

Maisyaroh, Iis (2014). Penerapan Metode Permainan Ular Tangga (Snakes Ledder) Untuk Meningkatkan Hasil Belajar Siswa Pada Mata Pelajaran IPS. Skripsi Universitas Islam Negeri (UIN) Syarif Hidayatullah: Jakarta.

Reysne, Febtika. (2017). Beragam Jurus Perkuat Humanivora. Jakarta: Direktorat Pembinaan Guru Pendidikan Dasar Direktorat Jendral Guru dan Tenaga Kependidikan Kementerian Pendidikan dan Kebudayaan.

Sudjana, Nana. (2016). Penilaian Hasil Proses Belajar Mengajar. Bandung: PT. Sinar Remaja Rosdakarya.

Zuldafrial. (2009). Belajar dan Interaksi Belajar Mengajar. Pontianak: STAIN Pontianak Press. 